\title{
Proteome dynamics and early salt stress response of the photosynthetic organism Chlamydomonas reinhardtii
}

Guido Mastrobuoni ${ }^{1 \dagger}$, Susann Irgang ${ }^{2 \dagger}$, Matthias Pietzke ${ }^{1 \dagger}$, Heike E Aßmus $^{1}$, Markus Wenzel', Waltraud X Schulze ${ }^{2}$ and Stefan Kempa ${ }^{1 *}$

\begin{abstract}
Background: The cellular proteome and metabolome are underlying dynamic regulation allowing rapid adaptation to changes in the environment. System-wide analysis of these dynamics will provide novel insights into mechanisms of stress adaptation for higher photosynthetic organisms. We applied pulsed-SILAC labeling to a photosynthetic organism for the first time and we established a method to study proteome dynamics in the green alga Chlamydomonas reinhardtii, an emerging model system for plant biology. In addition, we combined the analysis of protein synthesis with metabolic profiling to study the dynamic changes of metabolism and proteome turnover under salt stress conditions.

Results: To study de novo protein synthesis an arginine auxotroph Chlamydomonas strain was cultivated in presence of stable isotope-labeled arginine for 24 hours. From the time course experiment in 3 salt concentrations we could identify more than 2500 proteins and their $\mathrm{H} / \mathrm{L}$ ratio in at least one experimental condition; for 998 protiens at least 3 ratio counts were detected in the $24 \mathrm{~h}$ time point $(0 \mathrm{mM} \mathrm{NaCl})$. After fractionation we could identify 3115 proteins and for 1765 of them we determined their de novo synthesis rate. Consistently with previous findings we showed that RuBisCO is among the most prominent proteins in the cell; and similar abundance and turnover for the small and large RuBisCO subunit could be calculated. The D1 protein was identified among proteins with a high synthesis rates. A global median half-life of $45 \mathrm{~h}$ was calculated for Chlamydomonas proteins under the chosen conditions.
\end{abstract}

Conclusion: To investigate the temporal co-regulation of the proteome and metabolome, we applied salt stress to Chlamydomonas and studied the time dependent regulation of protein expression and changes in the metabolome. The main metabolic response to salt stress was observed within the amino acid metabolism. In particular, proline was up-regulated manifold and according to that an increased carbon flow within the proline biosynthetic pathway could be measured. In parallel the analysis of abundance and de novo synthesis of the corresponding enzymes revealed that metabolic rearrangements precede adjustments of protein abundance.

\footnotetext{
* Correspondence: Stefan.Kempa@mdc-berlin.de

${ }^{\dagger}$ Equal contributors

${ }^{1}$ Max Delbrück Center for Molecular Medicine Berlin, Berlin Institute for

Medical Systems Biology (BIMSB), Berlin, Germany

Full list of author information is available at the end of the article
} 


\section{Background}

Chlamydomonas reinhardtii belongs to the green algae and is the most widely used laboratory strain of the Chlamydomonas genus. Besides being a model organism for the study of fundamental biological questions, this species also gains more and more interest as a model for systems analyses and biotechnological applications. The release of the Chlamydomonas reinhardtii genome sequence in 2007 [1] set the basis for systems analyses and genome-wide studies and introduced Chlamydomonas as model organism; since then several systems level analyses have been performed. By applying metabolomic and proteomic analyses the genome annotation of Chlamydomonas was refined [2]. Based on the results from metabolomic studies, missing reactions from the metabolic network could be inferred [3] and ChlamyCyc, a web portal for systems analyses, was generated [4]. Also a stoichiometric genome-wide metabolic network from Chlamydomonas was constructed, that enables flux balance analyses [5]. However, such networks rely on stoichiometric basis and do not contain regulatory properties of the pathways. Furthermore, not all regulatory mechanisms are discovered to date.

Understanding the dynamics and stability of biological systems requires deeper insights in the temporal regulation of cellular processes. Specifically, the response of the photosynthetic apparatus to changing environmental conditions can be studied on a cellular level. Salt stress is detrimental to plant growth and increasing salt contaminated areas cause problems in agriculture. Thus, understanding adaptation strategies of higher plants to salt stress is of major importance. Furthermore, a better understanding of the salt stress response of green algae may allow engineering strains with an improved resistance to high salinity. Such strains could be cultivated in salt containing water but would keep the desired properties.

To date, methods are available and have been constantly improved to analyze the dynamics of the proteome, the transcriptome and the metabolome. Techniques for monitoring the dynamic changes within the proteome and metabolome are mostly based on metabolic labeling of metabolites and proteins using stable isotopes such as ${ }^{13} \mathrm{C}$ or ${ }^{15} \mathrm{~N}$ in combination with mass spectrometry or nuclear magnetic resonance (NMR) analyses. Most techniques were initially developed to analyze microorganisms or mammalian cell cultures, e.g. the mass isotopomer ratio analysis of $\mathrm{u}^{13} \mathrm{C}$ labeled extracts (MIRACLE) or the stable-isotope labeling in cell culture (SILAC) using arginine and lysine $[6,7]$.

Arginine and lysine are essential amino acids for many higher organisms and are commonly used for SILACbased proteomic studies. However, plants have the capability to synthesize all proteinogenic amino acids. Thus the application of stable-isotope labeled arginine in plants results in a partially labeled proteome [8,9]. To completely label plant proteomes ${ }^{15} \mathrm{~N}$ sources were applied [10].

In mammalian cells stable isotope labeled amino acids were applied to determine de novo protein synthesis $[11,12]$. However the application of ${ }^{15} \mathrm{~N}$ sources for pulse labeling resulted in an enormous complexity of the isotopic pattern of partially labeled proteins and peptides [13]. By improving the data analysis workflow Martin and co-workers could analyze the dynamic ${ }^{15} \mathrm{~N}$ incorporation into 92 peptides resulting in 40 proteins [14]. Other metabolic labeling techniques have also been used, however, only a limited set of plant proteins were monitored [15]. Recently, stable isotope labeled arginine has been used for metabolic labeling of proteins in Chlamydomonas to study proteome-wide response to anaerobic growth conditions [16].

In the present study we introduce a strategy to measure protein synthesis rates in Chlamydomonas. For the first time pulsed labeling with ${ }^{13} \mathrm{C}$-labeled arginine was applied in a photosynthetic organism. We thereby utilized the ability of Chlamydomonas to take up arginine as carbon and nitrogen source from the environment [17].

With this method we characterized the salt stress response of Chlamydomonas. The response of the micro alga Dunaliella salina to high salt stress was already analyzed on proteomic level [18]. Also the salt adaptation of Arabidopsis thaliana on metabolome level was investigated in a time course manner $[19,20]$. In contrast, the salt stress response of Chlamydomonas was not studied systematically.

Applying pulsed SILAC and GC-MS based stable isotope resolved metabolomics [21] we identified the major metabolic pathways altered in the early response of Chlamydomonas to salt stress. We observed that the proline-biosynthetic pathway displayed a strong response at the metabolite but not at the protein level. Our study is the first application of a combined proteomics and metabolite approach to study the stress respons of a green alga and represents the first comprehensive analysis of the early salt stress response of Chlamydomonas reinhardtii.

\section{Results}

In this study we analyzed the protein synthesis rate in Chlamydomonas reinhardtii by pulsed labeling using stable ${ }^{13}$ C6 arginine. For this purpose we made use of the arginine-auxotrophic Chlamydomonas strain CC1618, containing the mutated arg2 allele of the ARG7 gene. ARG7 encodes for the argininosuccinate lyase that catalyzes the last step of arginine biosynthesis [22,23]; 
consequently this strain requires arginine in the culture medium.

As a first step, we compared the incorporation of ${ }^{13} \mathrm{C}$ arginine into the proteome of a wild type Chlamydomonas strain (CC-125) versus the arginine auxotroph strain (CC-1618). We found an incorporation of ${ }^{13} \mathrm{C}$ arginine in both strains but the rate of incorporation was higher in the arginine auxotrophic strain (Additional file 1: Figure S1). Hence, for all further experiments the arginine auxotrophic strain was used.

Chlamydomonas cells were cultivated in three different conditions $(0 \mathrm{mM}, 100 \mathrm{mM}$ and $150 \mathrm{mM} \mathrm{NaCl})$ and harvested in a time course manner 1, 3, 8 and 24 hours after the supply of ${ }^{13} \mathrm{C}$ arginine. For this experiment, Chlamydomonas cells were cultivated in the condition of constant and slow growth (see Materials and Methods and Figure 1A). Under the chosen conditions the cell number increased by a factor of 1.3 after 24 hours. We have chosen these conditions to better distinguish de novo protein synthesis rates - related to the increase in biomass - from real protein turnover. Upon salt stress cell growth was mildly reduced (Figure 1A). In total, samples from 12 conditions were directly analyzed in duplicates and the protein heavy/light ratio ( $\mathrm{H} / \mathrm{L}$ ratio) for several hundreds of proteins in any of the samples could be calculated by the MaxQuant software [24]; a constant increase of the mean protein ratio was observed for all conditions (Figure 1B); also growth behavior and mean $\mathrm{H} / \mathrm{L}$ ratio displayed a linear co-behavior (Figure $1 \mathrm{C}$ ). The $\mathrm{H} / \mathrm{L}$ ratio reflects the protein synthesis rate since only newly synthesized proteins can incorporate ${ }^{13}$ C-labeled arginine. 998 proteins with three or more reported $\mathrm{H} / \mathrm{L}$ ratios (ratio count) could be obtained from the $24 \mathrm{~h} 0 \mathrm{mM}$ time point; to classify the proteins into functional classes the MapMan annotation was applied
$[4,25]$ and this protein set was used for further analyses (see Additional file 2: Table 1 for the complete list of proteins and the supplemental material).

We used this dataset to rank relative protein abundance (Abundance Index, AI) by dividing the measured intensity by the molecular mass of the protein. This simple calculation is comparable to the emPAI index [26], with the difference that the latter index is calculated as $\left(10^{\wedge}(\mathrm{PAI})-1\right)$, where PAI is the ratio observed/observable peptides for each identified protein. This calculation allows an intrasample protein abundance comparison. To test how reproducible this calculation may work we analyzed a mixture of 48 recombinant proteins distributed over an abundance range of 6 orders of magnitude. As it is reported in Additional file 3: Table 2 and Additional file 1: Figure S2, the abundance values calculated for proteins at each concentration level show a very narrow distribution. We extracted the quantitative values of photosystem II (PSII) proteins and of the small and large subunits of RuBisCO from the control time course data set. In agreement with literature data, which report RuBisCO subunits being the highest expressed enzymes of the Calvin-Benson cycle, the AI values for both subunits are among the top 10 in the dataset; moreover, these values reflect a nearly perfect $1: 1$ stoichiometry between the small nuclear-encoded and the large chloroplast-encoded subunits (Figure 2). Similarly, also proteins of the photosynthetic apparatus appear among the most abundant ones. Furthermore, we extracted the AI values and the $\mathrm{H} / \mathrm{L}$ ratios for the proteins of the photosynthetic apparatus in the $0 \mathrm{mM} \mathrm{NaCl}$ condition from the time course dataset, in order to monitor their behavior.

The $\mathrm{H} / \mathrm{L}$ ratios for RuBisCO large ( $\mathrm{rbcL}$ ) and small (rbcS) subunits were found constantly increasing in a similar way, indicating comparable synthesis rate and stability (Figure 3A), whereas the relative abundance was constant
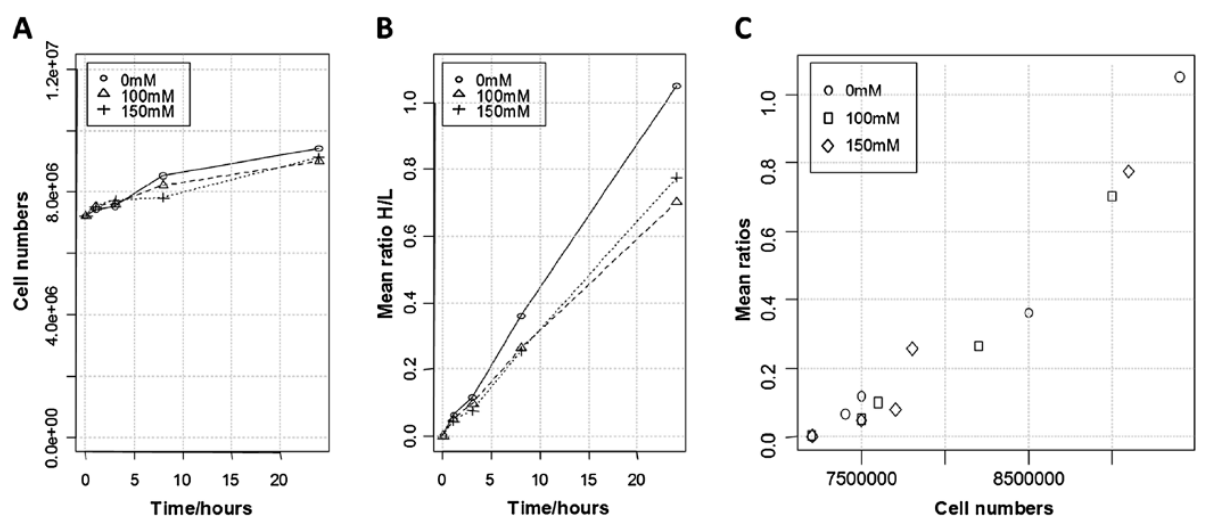

Figure 1 Cell growth and incorporation of stable isotope labeled arginine. Relation between observed protein ratio and cell number at $0 \mathrm{~h}$, $1 \mathrm{~h}, 3 \mathrm{~h}, 8 \mathrm{~h}$ and $24 \mathrm{~h}$ after addition of stable isotope labeled arginine upon 0 mM, $100 \mathrm{mM}$ and $150 \mathrm{mM} \mathrm{NaCl}$; [A] cell numbers, [B] mean of all protein ratios and $[\mathbf{C}]$ mean ratios plotted against cell numbers at all conditions. 


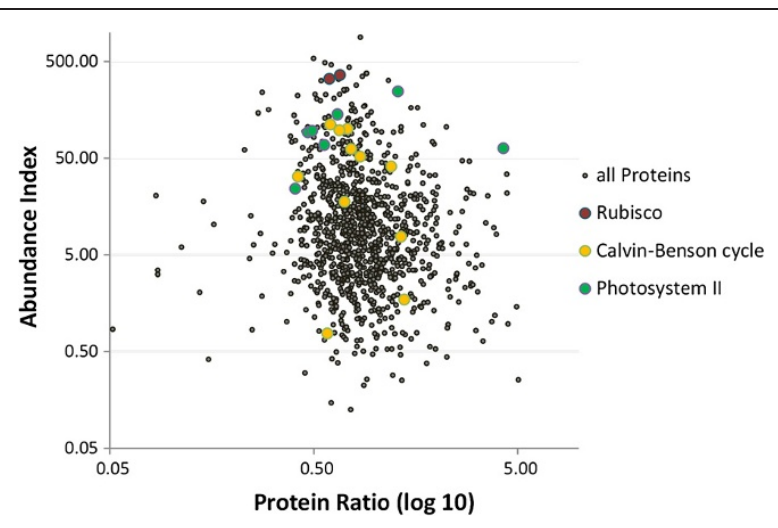

Figure 2 Genome scale overview of protein abundance and relative protein synthesis rates. Plot of protein abundance index versus protein $\mathrm{H} / \mathrm{L}$ ratios from a proteomic analysis of Chlamydomonas reinhardtii (strain CC-1618) grown under standard conditions and metabolic labeling of proteins with ${ }^{13} \mathrm{C}$-labeled arginine for 24 hours. All proteins with more than 4 ratio counts are shown in the diagram; Histones, RuBisCO and Photosystem II proteins (PS II) were selected and highlighted.

and with low standard deviation over the entire time course (Figure 3B). Among the proteins with high synthesis rate we found psbA, also termed ad D1 protein, which showed a synthesis rate higher than the other PSII proteins across the entire time course (Figure $3 \mathrm{C}$ and $3 \mathrm{D}$ ), in agreement with Pick and co-workers [15]. A list of selected proteins with the corresponding $\mathrm{H} / \mathrm{L}$ ratios for the $24 \mathrm{~h}$ time point and the AI is reported in Table 1; PSII proteins and proteins of the Calvin-Benson cycle are shown in Figure 4. The complete list of the proteins identified is available in the supplementary information (Additional file 2: Table 1).
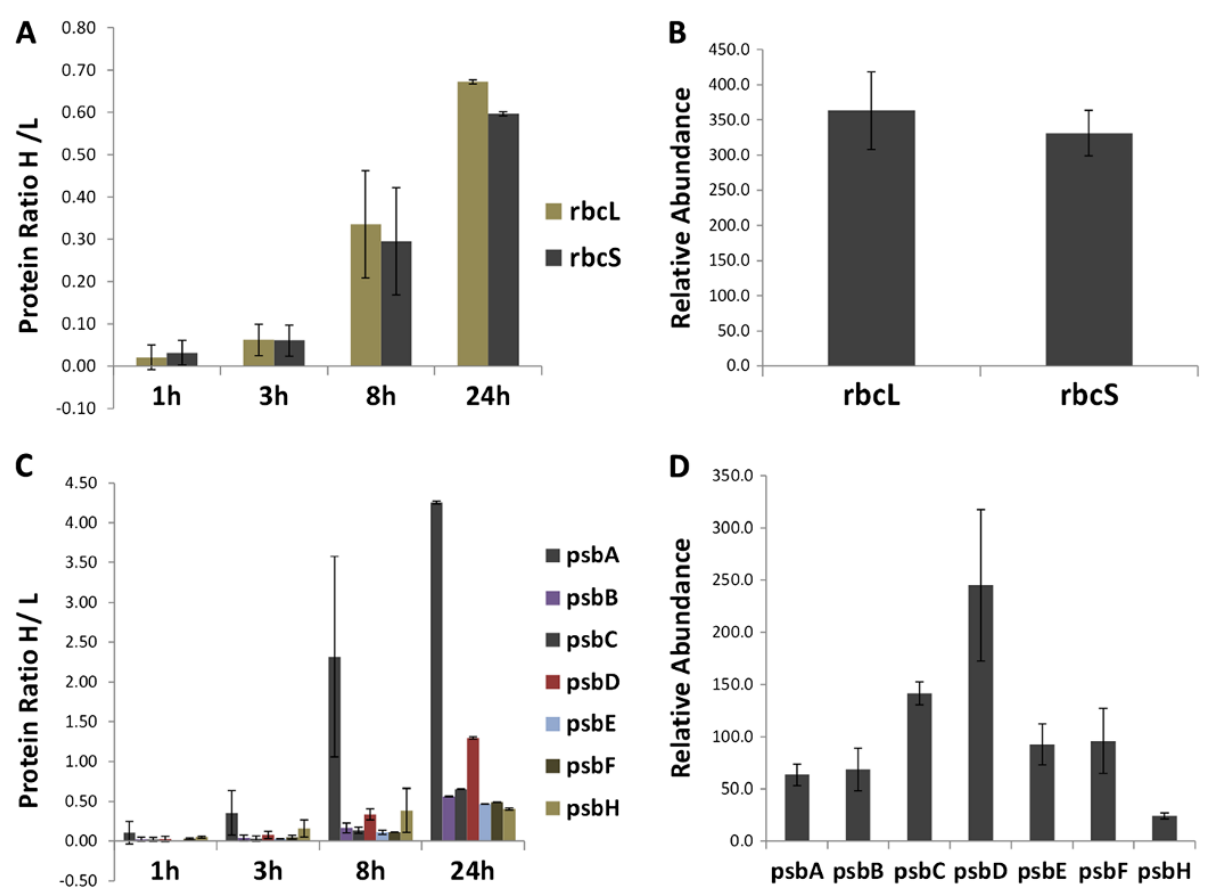

Figure 3 Time dependent incorporation of stable isotope labeled arginine and protein concentration. Reported are the $H / L$ ratios and relative protein abundance of RuBisCO large (rbcL) and small subunit (rbcS) as well as of photosystem II proteins. $[\mathbf{A}]$ Protein ratios of rbcL and rbcS at $0,1,3,8$ and $24 \mathrm{~h}$ from control conditions $(0 \mathrm{mM} \mathrm{NaCl})$ are shown with the standard deviations of all observed $\mathrm{H} / \mathrm{L}$ ratios of all corresponding peptides. [B] Bars show the average abundance of rbcL and rbcS from the $0,1,3,8$ and $24 \mathrm{~h}$ time points $(0 \mathrm{mM} \mathrm{NaCl})$. [C] Protein ratios of photosystem II proteins at $0,1,3,8$ and $24 \mathrm{~h}$ from the control condition ( $0 \mathrm{mM} \mathrm{NaCl}$ ). [D] Bars show the average relative abundance of photosystem II proteins from the $0,1,3,8$ and $24 \mathrm{~h}$ time points $(0 \mathrm{mM} \mathrm{NaCl})$. 
Table 1 Relative synthesis rates of selected proteins

\begin{tabular}{|c|c|c|c|c|c|c|c|c|}
\hline & Identifier & $\begin{array}{l}\text { MapMan } \\
\text { Bincode }\end{array}$ & Description & $\begin{array}{l}\text { Protein } \\
\text { Ratio }\end{array}$ & SD & $\begin{array}{l}\text { Ratio } \\
\text { count }\end{array}$ & $\begin{array}{l}\text { Abundance } \\
\text { index }\end{array}$ & SD \\
\hline \multirow{11}{*}{$\begin{array}{l}\text { Protein with } \\
\text { high Ratios }\end{array}$} & 143757 & & N/A & 5.0 & $+/-0.5$ & 3 & 0.3 & $+/-0.5$ \\
\hline & 186587 & & N/A & 4.9 & $+/-0.5$ & 4 & 1.5 & $+/-0.5$ \\
\hline & 195524 & 19.1 & magnesium chelatase & 4.5 & $+/-3.8$ & 5 & 1.0 & $+/-0.3$ \\
\hline & 191409 & & N/A & 4.4 & $+/-3.1$ & 5 & 21.8 & $+/-28.0$ \\
\hline & 194316 & 18 & $\begin{array}{l}\text { co-factor and vitamine } \\
\text { metabolism }\end{array}$ & 4.4 & $+/-3.2$ & 15 & 34.2 & $+/-17.2$ \\
\hline & psba & & psba & 4.3 & $+/-1.9$ & 12 & 63.3 & $+/-10.2$ \\
\hline & 195711 & 9.2 .2 & $\begin{array}{l}\text { mitochondrial electron } \\
\text { trtansport/ATP synthesis }\end{array}$ & 3.9 & $+/-3.3$ & 13 & 8.2 & $+/-5.1$ \\
\hline & 189624 & 1.1 .40 & $\begin{array}{l}\text { cyclic electron flow- } \\
\text { chlororespiration }\end{array}$ & 3.9 & $+/-0.1$ & 3 & 1.2 & $+/-0.7$ \\
\hline & 134058 & 34.16 & $A B C$ transporter & 3.8 & $+/-1.2$ & 16 & 9.6 & $+/-3.6$ \\
\hline & 177538 & & N/A & 3.7 & $+/-4.6$ & 12 & 1.0 & $+/-0.6$ \\
\hline & 129468 & 12.2 .2 & glutamine synthase & 3.6 & $+/-3.5$ & 7 & 20.5 & $+/-13.6$ \\
\hline \multirow[t]{4}{*}{ RUBISCO } & $\mathrm{rbcL}$ & 1.3 .1 & $\begin{array}{l}\text { RuBisCO large } \\
\text { subunit, rbcL }\end{array}$ & 0.7 & $+/-0.1$ & 32 & 363.1 & $+/-55.1$ \\
\hline & 108283 & 1.3 .2 & $\begin{array}{l}\text { RuBisCO small } \\
\text { subunit, rbcL }\end{array}$ & 0.6 & $+/-0.1$ & 15 & 331.4 & $+/-32.3$ \\
\hline & 193086 & 1.3.13 & $\begin{array}{l}\mathrm{rbcL} \mathrm{N}- \\
\text { methyltransferase }\end{array}$ & 1.4 & $+/-0.4$ & 4 & 1.7 & $+/-1.1$ \\
\hline & 128745 & 1.3.13 & RubisCO activase & 1.2 & $+/-0.2$ & 12 & 41.0 & $+/-11.8$ \\
\hline \multirow{10}{*}{$\begin{array}{l}\text { Calvin } \\
\text { Benson Cycle }\end{array}$} & 135614 & 1.3.11 & Ribulose phosphate-3-epimerase & 0.7 & $+/-0.2$ & 5 & 17.7 & $+/-6.7$ \\
\hline & 195910 & 1.3 .12 & Phosphoribulokinase & 1.3 & $+/-0.4$ & 6 & 7.7 & $+/-4.0$ \\
\hline & 24084 & 1.3.7 & Fructose-1,6-bisphosphate & 1.4 & $+/-0.0$ & 2 & 2.3 & $+/-1.6$ \\
\hline & 24459 & 1.3.6 & Fructose-1,6-bisphosphate aldolase & 0.8 & $+/-0.3$ & 18 & 51.9 & $+/-16.7$ \\
\hline & 141319 & 1.3 .8 & Transketolase & 0.8 & $+/-0.2$ & 23 & 62.1 & $+/-14.8$ \\
\hline & 129019 & 1.3 .4 & $\begin{array}{c}\text { Glyceraldehyde 3-phosphate } \\
\text { dehydrogenase A }\end{array}$ & 0.7 & $+/-0.1$ & 20 & 100.7 & $+/-13.7$ \\
\hline & 132210 & 1.3 .3 & Phosphoglycerate kinase & 0.7 & $+/-0.5$ & 16 & 96.8 & $+/-8.2$ \\
\hline & 102889 & 1.3.4 & $\begin{array}{l}\text { Glyceraldehyde 3-phosphate } \\
\text { dehydrogenase, nonphosphorylating }\end{array}$ & 0.6 & $+/-0.1$ & 5 & 0.8 & $+/-0.6$ \\
\hline & 189186 & 1.3 .9 & Sedoheptulose-1,7-bisphosphatase & 0.6 & $+/-0.2$ & 31 & 111.3 & $+/-21.9$ \\
\hline & 26265 & 1.3.5 & Triose phosphate isomerase & 0.4 & $+/-0.1$ & 7 & 32.4 & $+/-8.2$ \\
\hline \multirow[t]{7}{*}{ Photosystem II } & psbA & 1.1.1.2 & psbA & 4.3 & $+/-1.9$ & 12 & 63.3 & $+/-10.2$ \\
\hline & psbB & 1.1.1.2 & psbB & 0.6 & $+/-0.2$ & 25 & 68.6 & $+/-20.3$ \\
\hline & $\mathrm{psbC}$ & 1.1.1.2 & $\mathrm{psbC}$ & 0.7 & $+/-0.1$ & 29 & 141.3 & $+/-11.1$ \\
\hline & psbD & 1.1.1.2 & psbD & 1.3 & $+/-1.2$ & 15 & 244.8 & $+/-72.3$ \\
\hline & psbE & 1.1 .1 .2 & psbE & 0.5 & $+/-0.1$ & 3 & 92.7 & $+/-19.7$ \\
\hline & psbF & 1.1 .1 .2 & psbF & 0.5 & $+/-0.1$ & 4 & 95.8 & $+/-31.2$ \\
\hline & psbH & 1.1 .1 .2 & psbH & 0.4 & $+/-0.1$ & 4 & 24.2 & $+/-2.9$ \\
\hline
\end{tabular}

Protein list with the corresponding $\mathrm{H} / \mathrm{L}$ ratio at $24 \mathrm{~h}(0 \mathrm{mM} \mathrm{NaCl})$ and abundance index (Al) across the entire time course. Proteins are sorted in four functional groups: high synthesis rates, RuBisCO, Calvin-Benson cycle and Photosystem Il; Joint Genome Institute (JGI) protein identifier, MapMan bincode, a protein description, protein ratio and relative abundance index are reported for each protein.

To monitor a larger set of peptides - and subsequently proteins - we used a novel method for isoelectric-fractionationof peptides in solution [27]. In contrast to other isoelectric-focusing techniques, this method allows fractionation of any protein or peptide sample in the desired $\mathrm{pH}$ range within less than 3 hours with high sample recovery. With this method we analyzed the samples taken at 8 and 24 hours in absence of $\mathrm{NaCl}$ in 


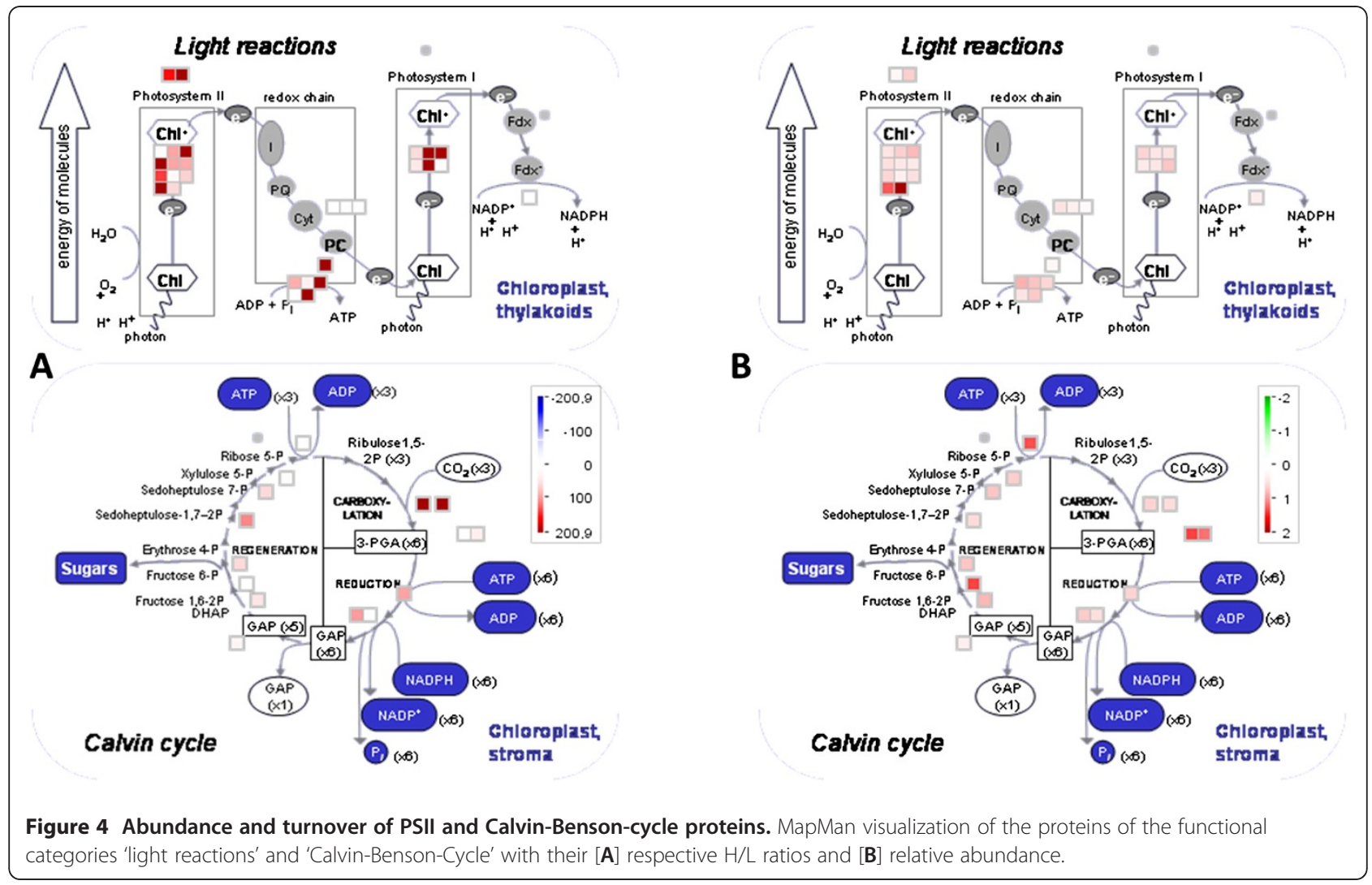

the culture medium. The fractionation prior the downstream MS analysis allowed us to identify more than 23.000 different peptides (versus 12,500 identified from all the 12 samples without fractionation) with a false discovery rate (FDR) of $1 \%$. The identified peptides could be mapped to 3115 proteins identified with at least 2 unique peptides and for 1765 of those a $\mathrm{H} / \mathrm{L}$ ratio was measured with at least 3 ratio counts in both conditions (Additional file 4: Table 3).

\section{Calculation of protein half lives}

To analyze protein dynamics for a large number of proteins we measured several time points, from 1 to 24 hours after addition of ${ }^{13} \mathrm{C}$ arginine. Hypothesizing that within $24 \mathrm{~h}$ no protein underwent degradation and was just produced according to the increase of biomass, all proteins would display a protein $\mathrm{H} / \mathrm{L}$ ratio of 0.3 (expected protein ratio). In contrast, the average ratio from all proteins was calculated to be 1.0, with values up to 6.0, thus a reasonable de novo protein synthesis in Chlamydomonas under this condition could be evidenced. Only a few proteins were found with a ratio below 0.3 . Those proteins may not be synthesized at the same speed as biomass is increasing (Figure 2). Assuming exponential growth, an exponential decay of the light protein present at $0 \mathrm{~h}$ time point and $100 \%{ }^{13} \mathrm{C}$ arginine incorporation into newly synthesized proteins, the half-life of proteins can be estimated [28]. Taken the increase in biomass of 0.3 times within $24 \mathrm{~h}$ and the assumption of exponential growth $(\mathrm{P}(\mathrm{t})=\mathrm{P} 0 * 2 \mathrm{t} /$ Tdouble $)$ resulted in a doubling time (Tdouble) of $63 \mathrm{~h}$. For the robust calculation of protein half-lives we used the individual $\mathrm{H} / \mathrm{L}$ ratios at $3 \mathrm{~h}, 8 \mathrm{~h}$ and $24 \mathrm{ht}$. We applied simplified linear regression (includes the time point $0 \mathrm{~h}$ with a $\mathrm{H} / \mathrm{L}$ ratio of zero) and calculated the half-lives of 710 proteins (Additional file 5: Table S4).

\section{Chlamydomonas Protein synthesis rates and metabolic alterations upon salt stress}

To analyze the salt stress response we cultivated Chlamydomonas with ${ }^{13} \mathrm{C}$-arginine in standard growth medium containing $0 \mathrm{mM}, 100 \mathrm{mM}$ or $150 \mathrm{mM}$ sodium chloride. The samples were collected in a time course manner after $1 \mathrm{~h}$, $3 \mathrm{~h}, 8 \mathrm{~h}$, and $24 \mathrm{~h}$. Each sample was analyzed by LC-MS based proteomics and GC-MS based metabolomics. From the proteomics analysis we could determine the relative protein synthesis rates of several hundred proteins (Additional file 1: Table 1). For all conditions we observed an $\mathrm{H} /$ $\mathrm{L}$ ratio increasing over time, with a slope depending on the salt concentration (Figure 1B). The average synthesis rate was highest under the control condition $(0 \mathrm{mM})$ and the lowest at $150 \mathrm{mM}$ sodium chloride. The protein ratio was 
clearly correlated to the increase of cell numbers at each time point (Figure 1C). To compare synthesis rates from $0 \mathrm{mM}, 100 \mathrm{mM}$ and $150 \mathrm{mM}$ the $\mathrm{H} / \mathrm{L}$ ratios from the $24 \mathrm{~h}$ time point from each condition were Z-transformed and plotted against each other (Figure 5). This transformation corrects for the underestimation of the $\mathrm{H} / \mathrm{L}$ ratio because of the metabolic labeling of proline and glutamate (Figure 6). The overlay of normalized protein ratios from $24 \mathrm{~h} /$ $100 \mathrm{mM}$ and $24 \mathrm{~h} / 150 \mathrm{mM} \mathrm{NaCl}$ compared to control conditions revealed a similar behavior of proteins upon the two stress conditions (Figure 5); even the ranking of proteins with up or down regulated $\mathrm{H} / \mathrm{L}$ ratios is the same (Table 2).

\section{Effects of salt stress on metabolism}

To monitor the metabolic response to salt stress a GC-MS based metabolome analysis was performed. With this technique we could identify the salt stress response at the metabolite level. To visualize the general behavior a principal component analysis (PCA) was performed; the PCA clearly separated samples treated with $100 \mathrm{mM}$ or $150 \mathrm{mM} \mathrm{NaCl}$ from the control samples. Interestingly, the $24 \mathrm{~h} / 100 \mathrm{mM}$ sample showed a very similar metabolite pattern compared to the sample taken after $1 \mathrm{~h}$ at $150 \mathrm{mM}$ (Figure 7A). Many metabolites showed a comparable response to salt stress. For example, at $100 \mathrm{mM} \mathrm{NaCl}$ proline concentrations reached a maximum after 24 hours, however, the same levels were reached at $150 \mathrm{mM} \mathrm{NaCl}$ already after $1 \mathrm{~h}$ (Figure 7A and 7C). These results indicate that Chlamydomonas can slowly adapt to $100 \mathrm{mM} \mathrm{NaCl}$, but displays a fast shock reaction at $150 \mathrm{mM} \mathrm{NaCl}$ concentration, concerted by a strong metabolic response. The overview graphic (Figure $7 \mathrm{~B}$ ) displaying the relative metabolite changes after $24 \mathrm{~h} / 100 \mathrm{mM}$ compared to the $24 \mathrm{~h}$ nonstressed control shows that a strong response can be observed in the amino acid metabolism. We have extracted the isotopomer distribution from the GC-MS mass spectra, as described in [21], and have calculated the changes of ${ }^{13} \mathrm{C}$ abundance for several metabolites. Careful inspection revealed that ${ }^{13} \mathrm{C}$ carbon atoms derived from ${ }^{13} \mathrm{C}$ arginine could be detected in downstream amino acids (Figure 6).

Already after 3 hours the percentage of ${ }^{13} \mathrm{C}$ label in proline was $10 \%$ and in glutamate $3 \%$ and then stayed constant up to $24 \mathrm{~h}$ under control conditions (0 mM). Upon salt stress the ${ }^{13} \mathrm{C}$-label was enhanced in proline and glutamate but not in putrescine compared to the control condition. Furthermore, upon salt stress proline levels increased substantially but glutamate levels only moderately indicating a distinct regulation of proline synthesis. Interestingly, the detected enzymes from the arginine to proline inter-conversion pathway did not show changes in abundance (Additional file 5: Figure 3).

\section{Discussion}

Using pulse labeling of proteins with stable isotope labeled arginine we were able to analyze the half-life of more than 710 proteins, and the relative synthesis rate of 1765 proteins in Chlamydomonas reinhardtii. This is the first report of a systems-wide analysis of protein dynamics from a photosynthetic organism. The new established method allows monitoring dynamics of protein synthesis and thus will open new perspectives for a better understanding of biological processes. In addition technical procedures have been improved enabling a higher sample throughput. Our improved method for in-solution peptide fractionation [27] prior to analysis on a nanoLC-LTQ-Orbitrap MS system yielded a high number of identified peptides

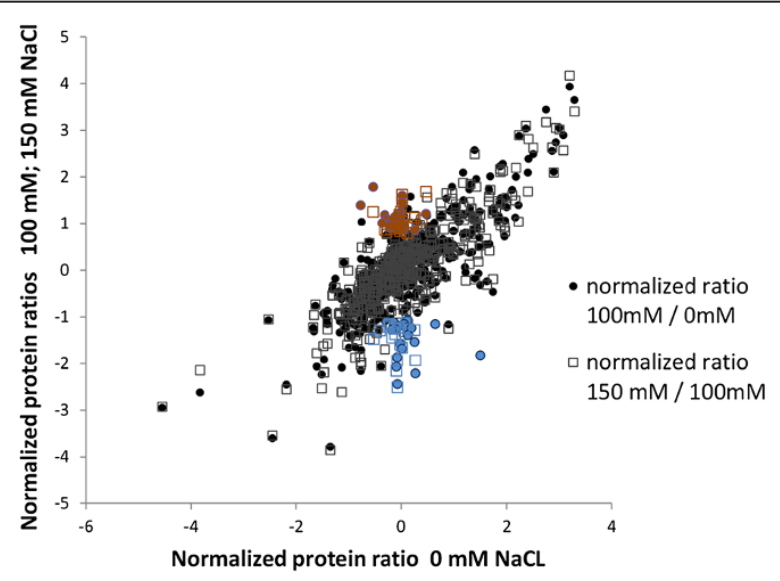

Figure 5 Relative protein synthesis rates upon salt stress. Normalized protein ratios obtained from Chlamydomonas after $24 \mathrm{~h}$ incubation with stable isotope labeled arginine upon salt stress (100 mM and $150 \mathrm{mM} \mathrm{NaCl}$ ). Normalized protein ratios of $24 \mathrm{~h} / 100 \mathrm{mM}$ and $24 \mathrm{~h} 150 \mathrm{mM}$ are plotted against protein ratios obtained after $24 \mathrm{~h} / 0 \mathrm{mM} \mathrm{NaCl}$. The upper and lower $5 \%$ of proteins with altered protein ratios at both salt conditions are marked with colors (red - up regulated and blue - down regulated). 


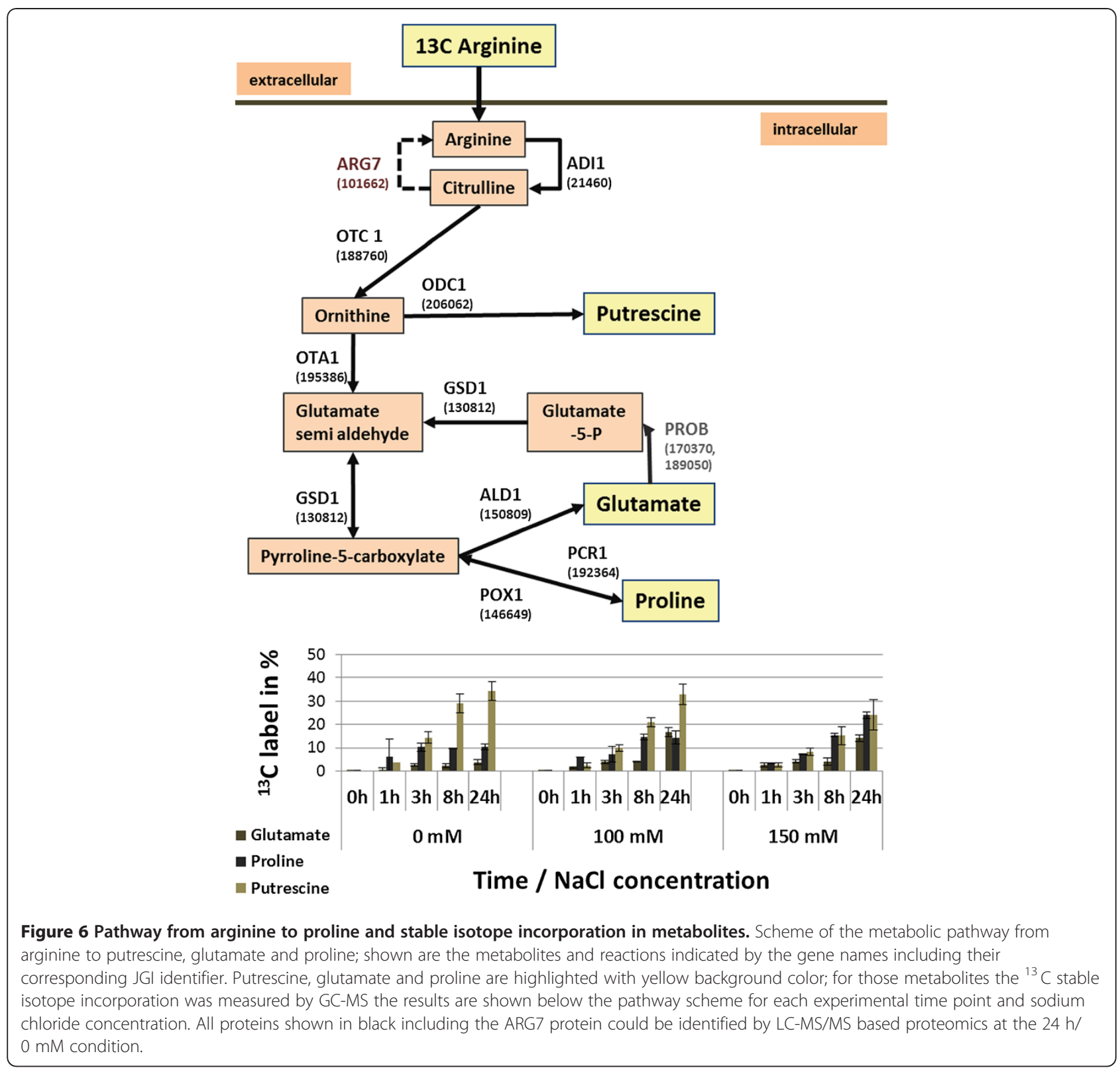

similar to other proteomics analysis of Chlamydomonas [16], but in a much shorter time period. Thus, our approach is suitable for comprehensive proteome analyses in a higher throughput manner. The data were used to calculate the relative abundance of proteins allowing for an inter-protein abundance comparison. In our study both $\mathrm{RuBisCO}$ subunits $\mathrm{rbcL}$ and $\mathrm{rbcS}$ showed a nearly perfect stoichiometry under the chosen conditions (Figure 2B). Also the half-life for both subunits was found comparable (Figure 2A). This is remarkable because rbcL is transcribed and translated in the chloroplast, while rbcS is encoded in the nucleus. This suggests the existence of regulatory mechanisms aimed to ensure a similar synthesis rate, highlighting the co-regulation of nuclear/cytosolic and chloroplastic processes. The currently available methods for absolute quantification of proteins as absolute SILAC [29] or quantitative targeted proteomics methods [30] are selective for defined proteins and thus are not applicable for discovery experiments. We observed constant protein concentrations at all time points under control conditions and thus assumed a steady state of our system (Figure 3B, 3D). Ongoing from this assumption we calculated a median protein half-life of 45 hours. Interestingly, this result is comparable to the median protein half life of mammalian cells of $46 \mathrm{~h}$ [28], which display a much higher proliferation rate. The protein synthesis rates in 
Table 2 Salt included changes of protein synthesis

\begin{tabular}{|c|c|c|c|c|c|c|}
\hline & \multirow[t]{2}{*}{ Protein IDs } & \multirow[t]{2}{*}{ Annotation } & \multirow[t]{2}{*}{ MapmanBin } & \multicolumn{3}{|c|}{ Normalised protein ratio } \\
\hline & & & & $0 \mathrm{mM}$ & $100 \mathrm{mM}$ & $150 \mathrm{mM}$ \\
\hline \multirow[t]{18}{*}{ up regulated protein ratios } & 147180 & NA & NA & -3.83 & -2.62 & -2.15 \\
\hline & 134305 & redox ascorbate and glutathione & 21.2 .1 & -4.54 & -2.95 & -2.93 \\
\hline & 131444 & S-assimilation, APR & 14.2 & -2.52 & -1.08 & -1.05 \\
\hline & 196360 & serine protease & 29.5.5 & -1.09 & 0.16 & 0.16 \\
\hline & 149072 & NA & & -0.76 & 1.03 & 0.49 \\
\hline & 119219 & PGM & 4.2 & -0.61 & 0.61 & 0.58 \\
\hline & 130434 & valine degradation & 13.2.4.3 & -0.64 & 0.21 & 0.48 \\
\hline & 196738 & FAP24 & & 1.40 & 2.57 & 2.48 \\
\hline & 129593 & Methionine degradation & 13.2.3.4 & -0.28 & 0.75 & 0.77 \\
\hline & 185032 & NA & & -0.11 & 0.98 & 0.92 \\
\hline & 162449 & Phosphoglycerate dehydrogenase & 13.1.5.1.1 & 0.04 & 0.96 & 0.93 \\
\hline & 24552 & Carbonic anhydrase & $8.3 ; 8.3$ & -1.63 & -0.76 & -0.74 \\
\hline & 123507 & serine protease & 29.5.5 & -1.25 & -0.18 & -0.37 \\
\hline & 187392 & Branched chain amino acid synthesis & 13.1.4.1 & 0.13 & 1.31 & 1.00 \\
\hline & 191617 & Asparate-tTNA ligase & 29.1.12 & -0.11 & 0.74 & 0.73 \\
\hline & 137300 & Starch phosphoylase & 2.2.2.2 & 0.06 & 1.15 & 0.88 \\
\hline & 123463 & Auxin metabolism & 17.2.1 & -1.31 & -0.41 & -0.54 \\
\hline & 195255 & Carbamoyl-phosphate synthase & 13.1.2.3.11 & -1.30 & -0.33 & -0.54 \\
\hline \multirow[t]{15}{*}{ down regulated protein ratios } & 126820 & Malate dehydrogenase & 8.2 .10 & 0.45 & -0.70 & -0.64 \\
\hline & 16132 & FMG1-2 & & -2.45 & -3.60 & -3.54 \\
\hline & 33411 & Oxygen-evolving enhancer protein2 & 1.1.1.2 & 0.32 & -0.91 & -0.81 \\
\hline & 24392 & Protein postranslational modification & 29.4 & 0.65 & -0.54 & -0.59 \\
\hline & 1670 & Protein targeting secretory pathway & 29.3.4.99 & 1.68 & 0.56 & 0.42 \\
\hline & 148898 & HPC2 & & -0.77 & -2.16 & -2.03 \\
\hline & 205988 & HSP70g & 20.2 .1 & 1.47 & -0.07 & 0.18 \\
\hline & 205649 & PSII polypeptide & 1.1.1.2 & 0.05 & -1.21 & -1.32 \\
\hline & 187761 & Protein degradation & 29.5 .9 & 1.23 & -0.05 & -0.22 \\
\hline & 132633 & Protein folding & 29.6 & 1.40 & -0.18 & -0.20 \\
\hline & 190311 & FHA transcription factor & 27.3 .48 & -0.38 & -2.07 & -2.05 \\
\hline & 112806 & Protein assembly and cofactor ligation & 29.8 & 1.75 & -0.47 & -0.19 \\
\hline & 196855 & Stress related & 20.2 .1 & 1.63 & -0.24 & -0.31 \\
\hline & 205900 & PSII polypeptide & 1.1 .1 .2 & 0.90 & -1.16 & -1.25 \\
\hline & 183363 & LHC-I & 1.1.2.1 & -1.35 & -3.79 & -3.85 \\
\hline
\end{tabular}

Proteins with increased or reduced protein ratios at $24 \mathrm{~h}$ at the $5 \%$ level from $100 \mathrm{mM}$ and $150 \mathrm{mM} \mathrm{NaCl}$ compared to proteins from the control culture ( $0 \mathrm{mM}$ ). The measured protein ratios were transformed ( $z$-transformation) to enable a comparison of protein ratios from all conditions.

Arabidopsis thaliana were analyzed using ribosome occupancy analyses and quantitative proteomics [31]. Even if the approaches are not directly comparable the estimated protein synthesis rates are in the same dimension. We could identify proteins with high de novo synthesis rates. Interestingly, a high turnover rate of the psbA protein was already observed more than two decades ago [15] and nowadays the regulatory nature of this protein in response to high light stress is well understood [32].

The intensity of the ${ }^{13} \mathrm{C}$ labeled peptides may be underestimated because of the interconversion of ${ }^{13} \mathrm{C}$ arginine into ${ }^{13} \mathrm{C}$ proline and its subsequent incorporation into newly synthesized proteins. In our study we could observe only a minor fraction of peptides containing ${ }^{13} \mathrm{C}$ proline; furthermore, the maximal ${ }^{13} \mathrm{C}$ 


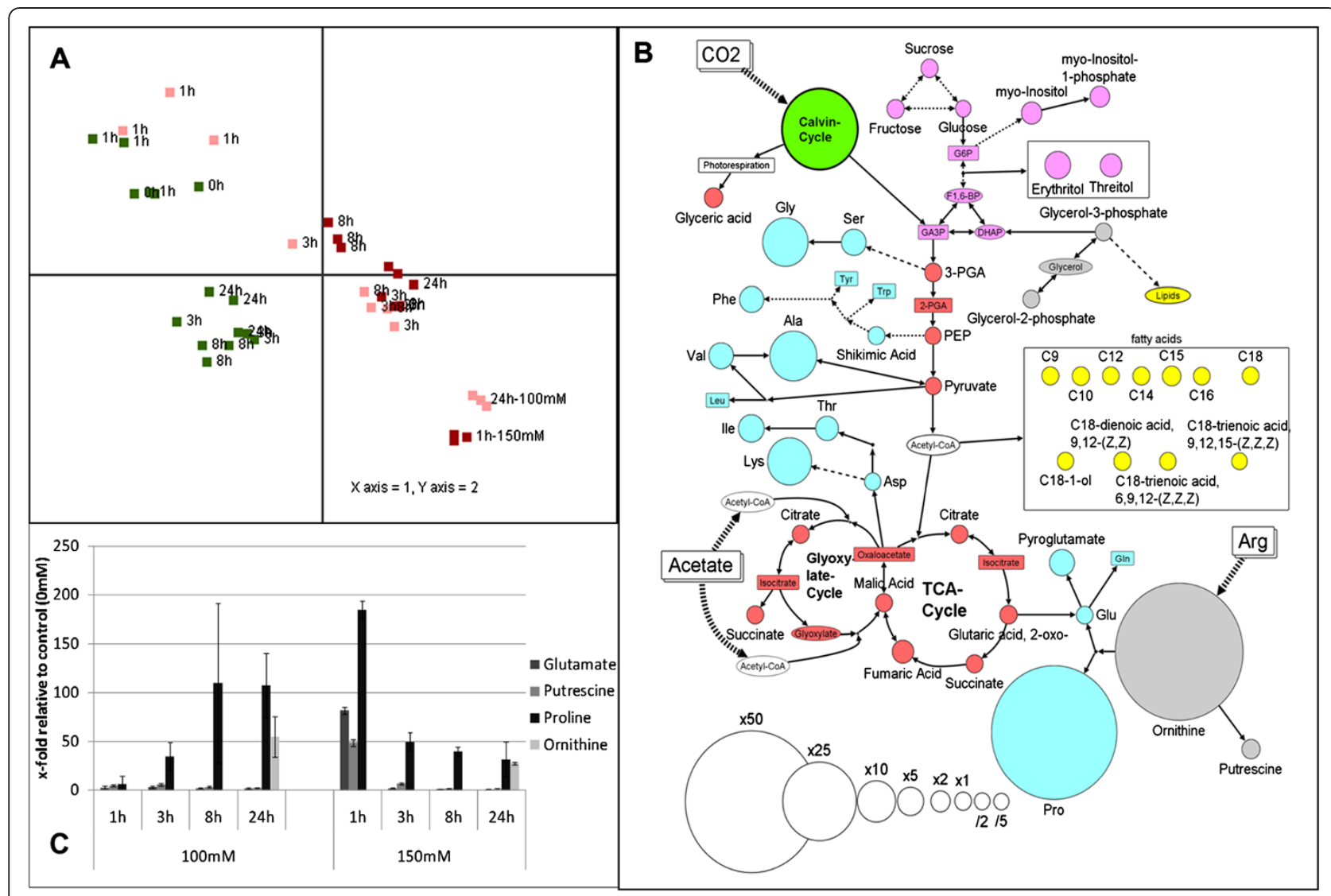

Figure 7 Dynamics of metabolite adjustments to salt stress. Overview about the metabolic changes of Chlamydomonas upon salt treatment; $[\mathbf{A}]$ principal component analysis (PCA) visualizing the metabolic changes measured by GC/MS based metabolic profiling, [B] relative changes of metabolite levels in Chlamydomonas after 24 hours treatment with $100 \mathrm{mM} \mathrm{NaCl}$ compared to $24 \mathrm{~h}$ time point of the control. The colors indicate different classes of metabolites: red and pink, intermediates of glycolysis and TCA cycle; light blue; amino acids, gray; others. [C] The temporal behavior of the amino acids proline, putrescine, glutamate and ornithine is shown at all time points compared to control (0 h/0 mM).

label of the free proline pool was $10 \%$ and the fraction of ${ }^{13} \mathrm{C}$ labeled glutamate was below $3 \%$ upon control conditions. Such a high degree of ${ }^{13} \mathrm{C}$ proline incorporation as observed by Heide and co-workers [33] could not be evidenced in our study. Thus we assume that the presented method is suitable to determine protein dynamics in experiments up to $24 \mathrm{~h}$.

We investigated the dynamics of the salt stress response of Chlamydomonas by an untargeted metabolome analysis. In particular we compared the protein turnover and the metabolic rates of the proline biosynthetic pathway. The metabolome analysis revealed that amino acid metabolism is strongly induced in Chlamydomonas upon salt stress. At a concentration of $100 \mathrm{mM} \mathrm{NaCl}$ a stepwise adaptation from $1 \mathrm{~h}$ to $24 \mathrm{~h}$ took place but already at $1 \mathrm{~h} / 150 \mathrm{mM}$ a salt shock reaction was observed. At $150 \mathrm{mM} \mathrm{NaCl}$ metabolite levels showed an immediate response at the 1 hour time point. This metabolic reaction clearly preceded proteome rearrangements and thus it may be driven by yet undiscovered posttranslational regulation. With increasing salt concentrations the label incorporation into proline and glutamate increased whereas the label in putrescine was comparable at all 3 conditions. This observation may be explained by the pathway structure (Figure 6) and the regulation of the flux trough this pathway. Hence, these data clearly suggest posttranslational activation of enzymes of proline biosynthesis and thus, rerouting of metabolism at high salt stress in Chlamydomonas reinhardtii.

\section{Conclusion}

Using large scale biochemical analyses it is possible to decipher regulatory steps within the cellular metabolic network, specifically the regulated enzymes and their mode of regulation. These studies will also help understanding stress induced metabolic alterations in higher photosynthetic organisms. In Chlamydomonas we found a proline accumulation upon salt stress; this reaction was also reported in higher plants and other algae [20,34,35]. Increases in proline and in mannitol could be detected after short term salt stress in the brown alga Ectocarpus 
siliculosus [36] and in Nicotiana tabacum prolonged salinity induced progressive accumulation of proline and myoinositol [37]. It was shown that artificially increased proline levels in Arabidopsis thaliana plants resulted in an improved resistance against freezing and high salinity [38] for review see: [39]. This indicates that the substantial proline accumulation might be a functional response in Chlamydomonas to counteract salt stress. Interestingly, carbohydrates were not found up-regulated in Chlamydomonas. We observed that the metabolic patterns of the two different salt concentrations were not reflected in the behavior of the proteome and that the proteomic responses to $100 \mathrm{mM}$ or $150 \mathrm{mM}$ were very comparable (Figure 5). Thus, we may provide evidence that metabolic rearrangements can happen within a short time period if necessary, whereas proteomic changes are more conservative. The observed phenomena may be an expression of a basic regulatory concept in biology; to provide metabolic flexibility with the expressed set of proteins and to restrict 'expensive' rearrangements of the proteome to long term environmental changes. Similar phenomena were reported within the yeast metabolism [40]. These results highlight the power of posttranslational regulation in order to adjust metabolic processes to the demand of the cell. The new established method enables the determination of protein turnover in Chlamydomonas and will allow gaining deeper insights in dynamic regulatory processes of photosynthetic organisms; the presented strategies and data will be beneficial for basic research, biotechnology and for agricultural improvements.

\section{Methods}

\section{Culture conditions and sampling}

The Chlamydomonas reinhardtii strain CC1618 (cw15, arg7, mt-) was stored on Tris-Acetate-Phosphatemedium (TAP) agar plates, supplied with $10 \mathrm{mM}$ arginine at $22{ }^{\circ} \mathrm{C}$ and a continuous light intensity of $150 \mu \mathrm{E} / \mathrm{m} 2$. Pre-cultures were grown in liquid TAP medium with $20 \mathrm{mM}$ Tris-buffer and $10 \mathrm{mM}$ L-Arginine up to OD of 1 on a rotary shaker at $110 \mathrm{rpm}$ and $100 \mu \mathrm{E} / \mathrm{m} 2 \mathrm{~s}$ continuous light intensity. The pre-culture was pelleted at $600 \mathrm{~g}$ for $2 \mathrm{~min}$ and dissolved in Hepes-Acetate-Phosphate (HAP) medium containing $5 \mathrm{mM}$ HEPES as a buffer and $10 \mathrm{mM}$

${ }^{13}$ C6-labelled Arginine (Fluka). The starting OD of the experiment was 0.7 ; for the salt stress analysis two other cultures were grown in the same medium with addition of $\mathrm{NaCl}$ to a final concentration of $100 \mathrm{mM}$ and $150 \mathrm{mM}$. For all measurements samples were taken from two independently grown cultures at the same time points (of $1 \mathrm{~h}$, $3 \mathrm{~h}, 8 \mathrm{~h}$ and $24 \mathrm{~h}$ ) after $\mathrm{NaCl}$ supply

\section{Proteomic sample preparation}

$2 \times 50 \mathrm{ml}$ of the cell-culture were collected and centrifuged for $10 \mathrm{~min}$ at $4{ }^{\circ} \mathrm{C}$ and the pellet was frozen. Cell pellets were resuspended in $600 \mu \mathrm{l}$ of buffer Urea $8 \mathrm{M}$ (Roth), ammonium bicarbonate $100 \mathrm{mM}$ (Fluka). Cells were homogenized in Dounce homogenizer; samples were then shortly centrifuged and the supernatant filtered using Whatman filters (0.45 um pore size). Protein concentration was determined by Bradford assay (Pierce); an average yield of $1 \mathrm{mg}$ of protein per sample was obtained.

The disulfide bridges of each protein sample were reduced in DTT $2 \mathrm{mM}$ (Sigma) for 30 minutes at $25{ }^{\circ} \mathrm{C}$ and successively alkylated in iodoacetamide $11 \mathrm{mM}$ (Sigma) for 20 minutes at room temperature in the dark. The samples were then diluted with 1.5 volumes of ammonium bicarbonate $100 \mathrm{mM}$ and incubated with LysC endoproteinase (WAKO) for 7 hours at $37^{\circ} \mathrm{C}$; after LysC digestion the samples have been further diluted with 1.5 volumes of ammonium bicarbonate $50 \mathrm{mM}$ and incubated with $10 \mu \mathrm{l}$ of immobilized trypsin (Applied Biosystems) under rotation for 16 hours at $37{ }^{\circ} \mathrm{C}$. After digestion all the samples have been desalted on Stage Tips [41] prior to LC-MS analysis. Samples from all experimental conditions were analyzed in duplicates.

For the isoelectric fractionation of peptides in solution $600 \mu \mathrm{g}$ of protein digest were desalted on SPE cartridges (3 M) following manufacturer instructions. The eluted peptides were then dried under vacuum and resuspended in $250 \mu \mathrm{l}$ bi-distilled water. This desalted peptide mixture was then fractionated in 10 fractions by isoelectrofocusing using a Microrotofor device (Biorad), on an in-solution $\mathrm{pH}$ gradient from $\mathrm{pH} 3$ to $\mathrm{pH}$ 10. The resulting fractions were then desalted on Stage Tip and the eluates dried and reconstituted to $50 \mu \mathrm{l}$ of $0.5 \%$ acetic acid in water.

Each fraction was analyzed in duplicate on a LC-MS/MS system (Eksigent nanoLC [Eksigent] and LTQ-Orbitrap Velos [Thermo]), using a 155 minutes gradient ranging from $5 \%$ to $60 \%$ of solvent B ( $80 \%$ acetonitrile, $0.1 \%$ formic acid; solvent $A=5 \%$ acetonitrile, $0.1 \%$ formic acid). Samples for the salt stress analysis were analyzed on the same LCMS/MS system, but with a gradient lasting 255 minutes.

Resulting raw data were analyzed using the MaxQuant proteomics pipeline v1.1.36 [24] and an in-house database containing swissprot protein data was used. Carbamidomethylation of cysteins and oxidation of methionins were chosen as static and variable modifications respectively; mass tolerance was set to $7 \mathrm{ppm}$ for the precursor and $0.5 \mathrm{Da}$ for the fragment masses; FDR was estimated by the frequency of hits from a decoy database, which was established by inverting the dataset used for proteome analysis and swapping each arginine and lysine with the preceding amino acid [42].

\section{Metabolomic sample preparation and analysis}

For metabolite analysis $2 \times 5 \mathrm{ml}$ were filtered through PVDF filter membranes $(0.6 \mu \mathrm{m})$ (Millipore) using a 
membrane pump with 10 mbar vacuum pressure. Filters with cells were frozen immediately in liquid nitrogen and stored at $-80{ }^{\circ} \mathrm{C}$. The frozen filters were extracted with $2 \mathrm{ml}$ of prechilled extraction buffer $(\mathrm{MeOH}: \mathrm{CHCl} 3: \mathrm{H} 2 \mathrm{O}$; 5:2:1) containing ${ }^{13} \mathrm{C}$-Sorbitol $2 \mathrm{ug} / \mathrm{ml}$ (Sigma) as internal standard under rotation at $4{ }^{\circ} \mathrm{C}$ overnight. The solution was centrifuged to spin down insoluble parts. $500 \mu \mathrm{l}$ of the supernatant were dried under vacuum and stored at $-20{ }^{\circ} \mathrm{C}$ for metabolomic analysis. Samples were prepared for GC-MS analysis as described previously [19]. The GC-MS chromatograms were processed with the Chromatof software (LECO). Data matrices for relative quantification were extracted from the mass spectra using MetMax software [21]. For statistical analysis intensities were corrected by internal standard and cellnumber. Data processing was performed with Microsoft Excel and R, PCA analysis was performed with TigrMev.

For ${ }^{13} \mathrm{C}$-incorporation study possible reaction products originating from arginine were identified using KEGG and ChlamyCyc [4] (See Figure 4). If the substance was found in our samples the mass shift between no label and full label was identified for multiple fragments per substance using the GMD (http://gmd.mpimp-golm. mpg.de/). Following mass isotopomers were extracted to calculate the ${ }^{13} \mathrm{C}$ label incorporation rate: Putrescine (4TMS) [86/87, 100/101/174/175], Proline (2TMS) [142/ 146], Glutamic acid (3TMS) [84/85, 100/101, 156/157, 246/248], Ornithine (3TMS)[174,175]. The tool MetMax extracted the intensities for all masses within the given ranges from the exported mass spectra. The percentage of label is calculated by dividing the intensity of the heavy mass by the intensity of the light mass and subtracting the natural ${ }^{13} \mathrm{C}$ abundance calculated from the control.

\section{Additional files}

Additional file 1: Table 1. contains all information about the identified proteins in the three salt conditions.

Additional file 2: Table 2. contains the data from reproducibility test for abundance index calculation.

Additional file 3: Table 3. contains all the proteins identified from the $8 \mathrm{~h}$ and $24 \mathrm{~h}$ samples in the $0 \mathrm{mM}$ condition, after fractionation, including their $\mathrm{H} / \mathrm{L}$ ratios.

Additional file 4: Table 4. contains the protein half-lives for the protein at 3, 8 and 24 hours.All the raw files form the MS analysis are available for download in mzML format at ftp://bbc.mdc-berlin.de/ gmastrob.

Additional file 5: Further information is present in additional material, which contains supplemental Figures 1,2 and 3 including legends.

\section{Competing interests}

The authors declare that they have no competing interests.

\section{Acknowledgements}

We thank Julia Diesbach for technical assistance and Jens Rupprecht for providing the Chlamydomonas strains. GM, MP, MW, HA and SK were founded by the BMBF and the Senat of Berlin through the Berlin Institute for Medical Systems Biology hosted at the MDC Berlin Buch. WS, SI were founded by the Max Planck Institute for molecular plant physiology.

\section{Author details}

Max Delbrück Center for Molecular Medicine Berlin, Berlin Institute for Medical Systems Biology (BIMSB), Berlin, Germany. ${ }^{2}$ Max-Planck-Institute for molecular plant physiology Potsdam-Golm, Berlin, Germany.

\section{Authors' contributions}

GM, performed proteomics analyses and data analysis; SI, performed the time course experiment; MP, analyzed the metabolites; HA, calculated protein halflives and corrected the manuscript; MW, performed data analysis and calculations; WS, made substantial contributions to conception and design; SK, planned the experiment, analyzed the data, wrote the manuscript. All authors read and approved the final manuscript.

Received: 10 August 2011 Accepted: 31 May 2012

Published: 31 May 2012

\section{References}

1. Merchant SS, Prochnik SE, Vallon O, Harris EH, Karpowicz SJ, Witman GB, Terry A, Salamov A, Fritz-Laylin LK, Marechal-Drouard L, et al: The Chlamydomonas genome reveals the evolution of key animal and plant functions. Science 2007, 318(5848):245-251.

2. May P, Wienkoop S, Kempa S, Usadel B, Christian N, Rupprecht J, Weiss J, Recuenco-Munoz L, Ebenhoh O, Weckwerth W, et al: Metabolomics- and proteomics-assisted genome annotation and analysis of the draft metabolic network of Chlamydomonas reinhardtii. Genetics 2008, 179 (1):157-166.

3. Christian N, May P, Kempa S, Handorf T, Ebenhoh O: An integrative approach towards completing genome-scale metabolic networks. Mol Biosyst 2009, 5(12):1889-1903.

4. May P, Christian JO, Kempa S, Walther D: ChlamyCyc: an integrative systems biology database and web-portal for Chlamydomonas reinhardtii. BMC Genomics 2009, 10:209.

5. Boyle NR, Morgan JA: Flux balance analysis of primary metabolism in Chlamydomonas reinhardtii. BMC Syst Biol 2009, 3:4.

6. Ong SE, Blagoev B, Kratchmarova I, Kristensen DB, Steen H, Pandey A, Mann $M$ : Stable isotope labeling by amino acids in cell culture, SILAC, as a simple and accurate approach to expression proteomics. Mol Cell Proteomics 2002, 1(5):376-386.

7. Mashego MR, Wu L, Van Dam JC, Ras C, Vinke JL, Van Winden WA, Van Gulik WM, Heijnen JJ: MIRACLE: mass isotopomer ratio analysis of U-13 Clabeled extracts. A new method for accurate quantification of changes in concentrations of intracellular metabolites. Biotechnol Bioeng 2004, 85 (6):620-628.

8. Gruhler A, Schulze WX, Matthiesen R, Mann M, Jensen ON: Stable isotope labeling of Arabidopsis thaliana cells and quantitative proteomics by mass spectrometry. Mol Cell Proteomics 2005, 4(11):1697-1709.

9. Naumann B, Stauber EJ, Busch A, Sommer F, Hippler M: N-terminal processing of Lhca3 Is a key step in remodeling of the photosystem Ilight-harvesting complex under iron deficiency in Chlamydomonas reinhardtii. J Biol Chem 2005, 280(21):20431-20441.

10. Engelsberger WR, Erban A, Kopka J, Schulze WX: Metabolic labeling of plant cell cultures with $\mathrm{K}(15) \mathrm{NO} 3$ as a tool for quantitative analysis of proteins and metabolites. Plant Methods 2006, 2:14.

11. Doherty MK, Whitehead C, McCormack H, Gaskell SJ, Beynon RJ: Proteome dynamics in complex organisms: using stable isotopes to monitor individual protein turnover rates. Proteomics 2005, 5(2):522-533.

12. Schwanhausser B, Gossen M, Dittmar G, Selbach M: Global analysis of cellular protein translation by pulsed SILAC. Proteomics 2009, 9(1):205-209.

13. Palmblad M, Mills DJ, Bindschedler LV: Heat-shock response in Arabidopsis thaliana explored by multiplexed quantitative proteomics using differential metabolic labeling. J Proteome Res 2008, 7(2):780-785.

14. Martin SF, Munagapati VS, Salvo-Chirnside E, Kerr LE, Le Bihan T: Proteome turnover in the green alga Ostreococcus tauri by time course $15 \mathrm{~N}$ metabolic labeling mass spectrometry. J Proteome Res 2012, 11(1):476-86.

15. Pick U, Gounaris K, Barber J: Dynamics of Photosystem II and Its Light Harvesting System in Response to Light Changes in the Halotolerant Alga Dunaliella salina. Plant Physiol 1987, 85(1):194-198. 
16. Terashima M, Specht M, Naumann B, Hippler M: Characterizing the anaerobic response of Chlamydomonas reinhardtii by quantitative proteomics. Mol Cell Proteomics 2010, 9(7):1514-1532.

17. Kirk DL, Kirk MM: Carrier-mediated Uptake of Arginine and Urea by Chlamydomonas reinhardtii. Plant Physiol 1978, 61(4):556-560.

18. Katz A, Waridel P, Shevchenko A, Pick U: Salt-induced changes in the plasma membrane proteome of the halotolerant alga Dunaliella salina as revealed by blue native gel electrophoresis and nano-LC-MS/MS analysis. Mol Cell Proteomics 2007, 6(9):1459-1472.

19. Kempa S, Rozhon W, Samaj J, Erban A, Baluska F, Becker T, Haselmayer J, Schleiff E, Kopka J, Hirt H, et al: A plastid-localized glycogen synthase kinase 3 modulates stress tolerance and carbohydrate metabolism. Plant J 2007, 49(6):1076-1090.

20. Kempa S, Krasensky J: Dal Santo S, Kopka J, Jonak C: A central role of abscisic acid in stress-regulated carbohydrate metabolism. PLoS One 2008, 3(12):e3935.

21. Kempa S, Hummel J, Schwemmer T, Pietzke M, Strehmel N, Wienkoop S, Kopka J, Weckwerth W: An automated GCxGC-TOF-MS protocol for batchwise extraction and alignment of mass isotopomer matrixes from differential 13 C-labelling experiments: a case study for photoautotrophic-mixotrophic grown Chlamydomonas reinhardtii cells. $J$ Basic Microbiol 2009, 49(1):82-91.

22. Konvalinkova V, Matagne RF, Loppes R: Induction and analysis of revertants from various arg-7 mutants lacking argininosuccinate lyase in Chlamydomonas reinhardi. Mutat Res 1974, 24(1):69-72.

23. Mages W, Heinrich O, Treuner G, Vlcek D, Daubnerova I, Slaninova M: Complementation of the Chlamydomonas reinhardtii arg7-8 (arg2) point mutation by recombination with a truncated nonfunctional ARG7 gene. Protist 2007, 158(4):435-446.

24. Cox J, Mann M: MaxQuant enables high peptide identification rates, individualized p.p.b.-range mass accuracies and proteome-wide protein quantification. Nat Biotechnol 2008, 26(12):1367-1372.

25. Thimm O, Blasing O, Gibon Y, Nagel A, Meyer S, Kruger P, Selbig J, Muller LA, Rhee SY, Stitt M: MAPMAN: a user-driven tool to display genomics data sets onto diagrams of metabolic pathways and other biological processes. Plant J 2004, 37(6):914-939.

26. Ishihama Y, Oda Y, Tabata T, Sato T, Nagasu T, Rappsilber J, Mann M: Exponentially modified protein abundance index (emPAl) for estimation of absolute protein amount in proteomics by the number of sequenced peptides per protein. Mol Cell Proteomics 2005, 4(9):1265-1272.

27. Adamidi C, Wang Y, Gruen D, Mastrobuoni G, You X, Tolle D, Dodt M, Mackowiak SD, Gogol-Doering A, Oenal $P$, et al: De novo assembly and validation of planaria transcriptome by massive parallel sequencing and shotgun proteomics. Genome Res 2011, 21(7):1193-1200.

28. Schwanhausser B, Busse D, Li N, Dittmar G, Schuchhardt J, Wolf J, Chen W, Selbach M: Global quantification of mammalian gene expression control. Nature 2011, 473(7347):337-342

29. Hanke S, Besir H, Oesterhelt D, Mann M: Absolute SILAC for accurate quantitation of proteins in complex mixtures down to the attomole level. J Proteome Res 2008, 7(3):1118-1130.

30. Kirkpatrick DS, Gerber SA, Gygi SP: The absolute quantification strategy: a general procedure for the quantification of proteins and posttranslational modifications. Methods 2005, 35(3):265-273.

31. Piques M, Schulze WX, Hohne M, Usadel B, Gibon Y, Rohwer J, Stitt M: Ribosome and transcript copy numbers, polysome occupancy and enzyme dynamics in Arabidopsis. Mol Syst Biol 2009, 5:314

32. Adir N, Zer H, Shochat S, Ohad I: Photoinhibition - a historical perspective. Photosynth Res 2003, 76(1-3):343-370.

33. Heide H, Nordhues A, Drepper F, Nick S, Schulz-Raffelt M, Haehnel W, Schroda M: Application of quantitative immunoprecipitation combined with knockdown and cross-linking to Chlamydomonas reveals the presence of vesicle-inducing protein in plastids 1 in a common complex with chloroplast HSP90C. Proteomics 2009, 9(11):3079-3089.

34. Liu J, Zhu JK: Proline accumulation and salt-stress-induced gene expression in a salt-hypersensitive mutant of Arabidopsis. Plant Physio 1997, 114(2):591-596

35. Cramer GR, Ergul A, Grimplet J, Tillett RL, Tattersall EA, Bohlman MC, Vincent D, Sonderegger J, Evans J, Osborne C, et al: Water and salinity stress in grapevines: early and late changes in transcript and metabolite profiles. Funct Integr Genomics 2007, 7(2):111-134.
36. Dittami SM, Gravot A, Renault D, Goulitquer S, Eggert A, Bouchereau A, Boyen C, Tonon T: Integrative analysis of metabolite and transcript abundance during the short-term response to saline and oxidative stress in the brown alga Ectocarpus siliculosus. Plant Cell Enviro. 2011, 34(4):629-42.

37. Zhang J, Zhang Y, Du Y, Chen S, Tang H: Dynamic metabonomic responses of tobacco (Nicotiana tabacum) plants to salt stress. $J$ Proteome Res. 2011, 10(4):1904-14.

38. Krasensky J, Jonak C: Drought, salt, and temperature stress-induced metabolic rearrangements and regulatory networks. J Exp Bot 2012, 63 (4):1593-608.

39. Kishor P, Hong Z, Miao GH, Hu C, Verma D: Overexpression of [delta]pyrroline-5-carboxylate synthetase increases proline production and confers osmotolerance in transgenic plants. Plant Physiolog 1995, 108:1387-1394.

40. Ralser $M$, Wamelink MM, Latkolik $\mathrm{S}$, Jansen $\mathrm{EE}$, Lehrach $\mathrm{H}$, Jakobs $\mathrm{C}$ Metabolic reconfiguration precedes transcriptional regulation in the antioxidant response. Nat Biotechnol 2009, 27(7):604-605.

41. Rappsilber J, Ishihama Y, Mann M: Stop and go extraction tips for matrixassisted laser desorption/ionization, nanoelectrospray, and LC/MS sample pretreatment in proteomics. Anal Chem 2003, 75(3):663-670.

42. Elias JE, Gygi SP: Target-decoy search strategy for increased confidence in largescale protein identifications by mass spectrometry. Nat Methods 20074(3):207-214.

\section{doi:10.1186/1471-2164-13-215}

Cite this article as: Mastrobuoni et al: Proteome dynamics and early salt stress response of the photosynthetic organism Chlamydomonas reinhardtii. BMC Genomics 2012 13:215.

\section{Submit your next manuscript to BioMed Central and take full advantage of:}

- Convenient online submission

- Thorough peer review

- No space constraints or color figure charges

- Immediate publication on acceptance

- Inclusion in PubMed, CAS, Scopus and Google Scholar

- Research which is freely available for redistribution 